Tatjana Borojević1, Drago Vuk', Nataša Petrović ${ }^{\text {, Dragoslav Slović² }}$

${ }^{1}$ University of Maribor, Faculty of Organizational Sciences, Slovenia

${ }^{2}$ University of Belgrade, Faculty of Organizational Sciences, Serbia

\title{
The Level of Youth Activism: Case Study of the City of Belgrade
}

UDC: $316.346 .32-053.6(497.11) " 2007 / 2014 "$

DOI: 10.7595/management.fon.2015.0023

During the period from 2007 to 2014, and in addition to huge institutional changes, large steps were taken in the field of youth policy in the Republic of Serbia in order to create national resources which would have influence on the improvement of the youth status and life. On the other hand, the practice shows that the existence of the national framework for youth support, as a local service network intended for youths, is not a crucial prerequisite to change the current situation when it comes to improving the quality of life of young people, but that the existence of the critical level of youth activism is a key driving force that leads to changes. This paper presents an overview of the level of youth activism in the city of Belgrade. The results show that young people accept a proactive attitude to life when it comes to their personal or family problems and issues whilst the engagement in the social field and especially a political one are not seen as a preferable type of behaviour.

Keywords: youth, youth activism, participation, level of youth activism

\section{Introduction}

There is no universally accepted nor one and only definition of "youth". Thus, youth may be defined as a relatively particular ensemble which each society identifies as such, and generally represents the age group, the socalled young generation ranging from 14 to 30 years of age. Of course, it is difficult not only to determine and define the age limit of youth and the youths, because the formal definitions of this life age differ among the institutions of the United Nations, which define youth "as persons between 15 and 24 years of age" (UN, 2015); "European Union (EU) - the current political definitions of youth from European countries and EU institutions are defined as members of youth groups that are between 15 and 25 years of age, or in some cases between 14 and 30 years of age, with the age limit varying by the field of study, i.e., whether it comes to education, health, employment, financial assistance, etc." (Bendit, 2006). "Youth is a particular period of life which signifies not only biological and psychological maturing but also the process of inclusion of an individual into society. During this period young people are expected to develop skills and abilities to be able to take part in all areas of social action. The process of inclusion of an individual into society usually lasts until reaching an adequate level of social autonomy, responsibility and independence" (Jović-Lazić, 2004). "Youth is shorter with those groups of young people who are less educated whereas it is a longer time path to grow up when it comes to young people who receive the longest education. In countries in transition, such as the Republic of Serbia, prolonged youth is often a matter of intimidation. In regards to how their lives are to be considered the youths in Serbia are asking that upper youth limit be defined as thirty years of age." (Conference Advisory Committee, 2007).

"In the Republic of Serbia, in the National Youth Strategy, the youths are defined as people between fifteen to thirty years of age. In the Republic of Serbia there are about a million and a half young people which in comparison to the total population number make twenty percent." (Ministry of Youth and Sports, 2008). In recent years the current situation in the Republic of Serbia has been characterized by a severe economic crisis which, with the existence of the transitional development concept, stipulates the general poverty in society, particularly vulnerable population groups which include the young; the challenges they are facing are huge. Hence the decision to move the youth upper age limit to thirty years of age.

The specifics of the Republic of Serbia are reflected in the radical systemic changes, i.e., in post-socialist transformation (transition), thus revealing a highly multidimensional process which equally deeply entails 
economic, political and cultural subsystems of the global society whilst in every-day frame it impacts the living conditions of groups and individuals, redefining their relations, changing behaviours, expectations and perspectives. The status of social devastation that occurs as a consequence of the catastrophic social events (inter ethnic wars, the collapse of the economic system, the deterioration of public services and institutions, value decline...) struck various social aggregates and groups with different intensity (Jović-Lazić, 2004). The catastrophic social events are not of equal dimensions hence they are not homogeneous. These events are marked with deep cleavages: on one side there are modern and on the other one anti-modern trends; on one side there is the past whilst on the other there is the future; on one side there is parochialism and on the other mondialism; on one side there is an authoritarian regime and on the other there is democracy; on one side there is a traditional opinion whilst on the other there is rationality; on one side there is an ethnic and on the other there is a civil state. The youths are the first to respond to social changes and shifts and they are the first ones who are affected by the consequences of these changes and, in the opinion of a number of authors, the young represent one of the most vulnerable groups in the transition process.

Furthermore, the importance of youth can be seen in the National Youth Strategy For the Period 2015-2025 of the Republic of Serbia (Ministry of Youth and Sports, 2015):

"The Republic of Serbia recognizes young people and their special and important role in the society. Young people are the present and the future of our society, a resource of innovations and a driving force of the development of the society. Therefore, it is required that it should be continuously and systematically invested in youth development and that a partnership be established between the young and the state in order to increase the active participation of young people in the society, encourage their social integration and ensure their inclusion in the development of youth policy."

The above mentioned overview of the situation points to the fact that a lot of activities were conducted at the national and local levels so that young people get a greater variety of content which will improve their status. All this resulted in a need to measure and analyse the level of youth activism and participation in a local community, also being addressed in this paper. As a preliminary study based on a case study on attitudes of young people living in the City of Belgrade and including 1,427 respondents, the paper showed not only good preliminary results but also provided answers to the following questions: (1) Do young people in the City of Belgrade accept a proactive attitude to life when their personal or family issues and events are in question and especially when they are not interested in political issues? (2) Do young people participate in the work of organizations and institutions to a very small degree even in those which have "youth" as their prefix or are basically intended for young people? (3) Is there a significant reserve of the youths against politics and is it true that politics is not a significant subject of interest to the young?

\section{Youth activism}

"Activism has increasingly become a growing interest among public relations scholars" (Ciszek, 2015). Activism can be defined as a process in which a group of people:

- put pressure on organizations or other institutions to change polices, practices, or conditions that they find problematic (Smith, 2005)

- strive to raise awareness, change attitudes, and encourage/discourage specific actions (Taylor \& Das, 2010)

- target social norms, embedded practices, policies, or the dominance of some social groups (Zoller, 2009; Ciszek, 2015).

Also, activism is a term describing a volunteer culture of political participation at various levels, be it a struggle over specific and local issues or a universal criticism of social and political systems, as well as the voice of the young people, gathered around the common idea of making a social change (Borojevic, Petrovic \& Vuk, 2014).

Generally speaking, activism (as well as the specific forms of activism) has its foundation in value orientation wherein it is examined whether or not it is good to be committed both for you and for others. Regardless of how absurd the situation might seem where the question of one's commitment is valued in general, certain social circumstances or characteristics of individuals often lead to fatalism which is manifested in the attitude "no matter what we do, someone else/something else decides for us". The situation may be even more drastic when it comes to activism towards improving the status of others, to solidarity and altruism. Activism as a value orientation is a very complex phenomenon because it contains at least two aspects: 
- activism as a preferable type of behaviour in the process of meeting the interests and needs of others (which is basically founded on altruism or "humane oriented unselfishness"),

- activism as a type of behaviour directed towards meeting personal interests and needs (which is basically founded on egoism or "self-centeredness") (CeSID \& Ministry of Youth and Sports, 2007).

There are different forms of activism aimed at certain social issues such as economic activism (boycotts, strikes), lobbying, media activism, propaganda, nonviolent confrontation, violent confrontation (riots, and even terrorism), demonstrations, petitions, so-called civil disobedience, etc. Numerous examples can be found of successful actions that have encouraged the public to think, have raised ethical considerations, have examined the legitimacy of the government and have created a social climate that made it necessary for the politicians, those who make decisions, to change their opinions, and those were successful because they were initiated and accomplished by encouraging enthusiasm, optimism, experience and good will.

Youth activism has its own forms (Hopkins \& Todd, 2015):

- engagements with immigration systems and debates (Cahill, 2010; Crawley, 2010),

- political engagements (Hopkins, 2004; Hopkins, 2007; Horschelmann, 2008),

- performance of citizenship (Staeheli, Attoh, \& Mitchell, 2013),

- everyday emotional geopolitics (Pain, Panelli, Kindon, \& Little, 2010),

- the political worlds of children (Elwood \& Mitchell, 2012; Kallio \& Hakli, 2011; Mitchell \& Elwood, 2013).

Active participation of the youth in solving local community issues and issues universal to all people at all places is important not only for their healthy growing-up but also for obtaining a better quality functioning of any society.

In the context of activism we must mention volunteerism as a basis of activism. Volunteerism may be defined as an activity of any individual that can make a contribution in time, skills and knowledge through voluntary actions in order to achieve development and peace (UNV, 2015).

Volunteerism has various forms and meanings. It is heavily influenced by history, politics, religion and culture of a particular region. However, it is possible to determine some key characteristics of what defines each voluntary activity. The common denominators of voluntary work are:

- free-of-charge work,

- voluntary work,

- work that takes a certain amount of time (a certain number of hours of engagement),

- work aimed at achieving the well-being of other people (aid directed towards people with whom a volunteer is not in family relations).

\section{Research methodology}

The aim of this research is to measure the level of the youth activism in the City of Belgrade. For the purpose of the study, the authors used the data from public opinion survey on a representative sample of the young people aged 15 to 30, conducted by the Strategic Marketing Agency for the purposes of the Youth Office of the City of Belgrade (CeSID \& Ministry of Youth and Sports, 2007). The sample included 1,427 respondents. The multistage sample was designed by making a sample out of 150 polling stations in the City of Belgrade which are representative of the level of the capital city. The data were collected by direct interviews with respondents.

The methods for studying the levels of youth activism include a theoretical part where the descriptive method was used (collecting literature, reports and Internet sources) and an empirical part where the data were gathered during interviews.

The research findings are, except for the area of the whole City of Belgrade, also representative for the socalled three circles of Belgrade which the report names Belgrade 1, Belgrade 2 and Belgrade 3 . This division is made on the experience from previous research, i.e., on the basis of the substantial heterogeneity of the capital city in many respects, which is reflected upon the public opinion and indicates significant differences among different areas of the capital. The division is not of administrative nature and is made according to the type of neighbourhood and distance from the city centre. According to this division, Belgrade 1 consists of the central city municipalities (Novi Beograd, Stari Grad, Vracar) and of parts of the municipalities which 
are partially included in the central city zone. The second circle, Belgrade 2, includes a wider city centre (as well as urban areas of the suburban municipalities (Mladenovac, Lazarevac, Sopot, Barajevo, Surcin), whilst Belgrade 3 covers rural parts of all the municipalities of the city.

The description of the research sample is given in Table 1.

Table 1: Research sample (Resource: CeSID \& Ministry of Youth and Sports, 2007)

\begin{tabular}{|c|c|}
\hline \multicolumn{2}{|c|}{$\begin{array}{l}\text { Gender: } \\
\text { 1. female }-49 \text { percent, } \\
\text { 2. male }-51 \text { percent. }\end{array}$} \\
\hline Age: & $\begin{array}{l}\text { - from } 15 \text { to } 19 \text { years of age }-28 \text { percent, } \\
\text { - from } 20 \text { to } 25 \text { years of age }-30 \text { percent, } \\
\text { - from } 26 \text { to } 30 \text { years of age }-42 \text { percent. }\end{array}$ \\
\hline Educ & 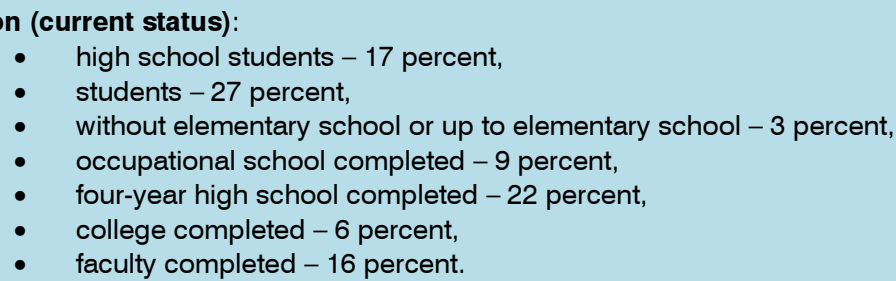 \\
\hline
\end{tabular}

The main goals of our research were to obtain answers to three questions:

- Q1: Do young people in the City of Belgrade accept a proactive attitude to life when their personal or family issues and events are in question and especially when they are not interested in political issues?

(Explanation: The assumption that the youth demonstrate a very low level of desire for an active and participatitative exploit in social flows both at the national and local levels (the City of Belgrade) is seen in a very low interest of the youth to be involved in the planning process at the level of the City of Belgrade which defines the guidelines of the youth policy in the period of five years.)

- Q2: Do young people participate in the work of organizations and institutions to a very small degree, even in those which have "youth" as its prefix or are basically intended for young people?

(Explanation: Having in mind that reducing youth unemployment is one of the national priorities in the field of the youth policy, poor involvement of the youth in the work of organizations and institutions, even those that address the basic issues of the youth, deprives the youth from important information and experience that directly affect the socio-economic status and cause a large percentage of unemployed youth.)

- Q3: Is there a significant reserve of the youth against politics and is it true that politics is not a significant subject of interest to the young?

(Explanation: The general impression is that the youth are fundamentally uninterested in the political participation, i.e., in a more active involvement in the political life of the City of Belgrade believing that "it is not possible to change the current situation" and that political decisions which are crucial to their life are not brought in accordance to their needs but in compliance with the "instant needs of political parties".)

\section{Results and discussion}

Activism as a value orientation, i.e., as a desirable and acceptable type of behaviour was researched in such a way that respondents were given a set of ten statements of which five treated activism in an affirmative sense. The other five suggested that social or personal involvement did not make much sense.

At the level of value orientation, we can be satisfied with the attitude of the youth in the City of Belgrade:

- The extent of agreement with the statements that speak about activism in an affirmative sense: as much as 72 percent of the youth claim to be "constantly on the move", that they cannot sit still and 
do nothing, or undertake something, or be inactive. The intensity of the statement is strong, because out of this number of respondents 43 percent of them absolutely agree with this statement, while 29 percent tend to generally agree.

- The agreement with the statement that they want to achieve in life not only what others expect of them but more than that: 63 percent of respondents assert this attitude. However, every fifth respondent is not sure about this statement while 18 percent of the youth do only what others expect them to do.

When we "shift" activism from the personal field to the field of public life, we see that young people are to a large extent sceptical about whether they should be active in social and particularly in political life:

- Although 40 percent of them agree that ordinary people can influence politics and politicians, more than one-third (36 percent) disagree while one-quarter are indecisive.

- Less than half of young people believe that politics and politicians can be influenced, which is a worrying fact which speaks not only about the youth, but also about the character of our policy which will be discussed further on in this report.

It is a very similar situation with the statement about how it is important to the youth that they can have discussions on social issues:

- Although there is a predominance of positive response to this claim, the advantage is very small and the responses are almost evenly distributed among those who agree, who disagree and who are indecisive.

- To a large number of young people, therefore, it would not be a "handicap" if they were forbidden to talk about social issues.

When it comes to the statement about the public appearance, the results show that:

- 36 percent of responders declared that they love appearing in public and be engaged in solving problems through speaking publicly.

- 38 percent of them were indecisive.

- 29 percent of young people expressed disagreement.

What causes concern is that:

- More than a half of the respondents do not like to deal with social problems; they would rather leave them to someone else.

- They themselves were concerned only with their own problems.

A very similar situation is with the next statement (although young people constitute "the most rebellious" part of the population):

- 46 percent of young would not "uselessly fix up already established mechanisms in society" and thus address social issues.

- 26 percent of them may be expected to do such things.

In the case of showing interest in the state issues, young people were divided into two almost equal groups:

- Those who agree and those disagree with the fact that they are not interested in the state issues because they have enough of their own.

However, as soon as we get back to the area of personal issues, young people show a remarkable degree of proactive attitude, thus:

- More than a half disagree with the fact that we should not try to change anything in our personal lives.

- 71 percent do not reconcile with giving up before bigger obstacles.

The key aim of this study has been to provide answers to questions about the way that young people treat activism in the City of Belgrade. The findings of our research demonstrated that:

- As much as 72 percent of the youth claim to be "constantly on the move" that they cannot sit still and do nothing, not undertake anything, or be inactive. The intensity of the statement is strong because 43 percent of this number of respondents absolutely agree with this statement, while 29 percent tend to generally agree. Although 40 percent of them agree that ordinary people can influence politics and politicians, more than one-third (36 percent) disagree while one-quarter is indecisive. The point of this finding is that less than half of young people believe that politics and politicians can be influenced 
which is a worrying fact as it speaks not only about the youth but also about the character of our policy. More than a half of the young respondents do not like to deal with social problems, they would rather leave them to someone else; they themselves are concerned only with their own problems. Although young people constitute "the most rebellious" part of the population, 46 percent of them would not "fix up the situation" and thus address social issues, while 26 percent may be expected to do so.

- The results reveal that almost half of the young people (48 percent) have absolutely no contact with either one of organizations, in the form of either passive or active membership. 29 percent of young people show a very low degree of participation which is reflected in their passive membership in at least one organization and at most in three organizations. Nor is it possible to say that they are institutionally networked because since passive membership does not necessarily mean anything, is a dead letter, for more than three-quarters of young people (77 percent) we may surely conclude, according to our research, that they are institutionally passive. One-fifth of the young (21 percent) indicate that they participate to a certain level, while 2 percent of young people are active in various organizations, what is more, in several of them. Participation in organizations depends on the level of education of young people or their current status in the educational process. Those who are now students show the highest level of formal networking in an institution, and then there are high school students, i.e., those who still do not work and who obviously have more time and need for additional engagement. Those who have completed their education already work or are occupied with finding a job and have no special interest in engaging in an organization. Participation in organizations obviously does not depend on the level of education, in the sense in which it is expected that those who have completed a higher level of education are more active, because it showed that those with higher or university education are at an average level in terms of participation in the work of organizations. Participation in organizations, therefore, depends more on the amount of free time and on how that time is organized.

- On an average, a quarter of young people are regularly informed about politics through the media (26 percent), slightly more than a half of them get informed from time to time (55 percent) and every fifth respondent (19 percent) never does it. This number is significantly different in the groups of young people - being informed about politics through the media increases with the age of the respondents. Further on, only 14 percent of young people regularly talk about politics with friends; half of them do it sometimes, and a third of them never. Again, age is a significant correlate of this indicator of political participation. The third indicator means interest in politics at a crucial political event, such as elections. Half of young people (49 percent) do not follow anything in relation with elections, and this is broadcast by media; 38 percent do so sometimes, and only 13 percent regularly. In this respect, also, the youngest show the least interest.

\section{Conslusion}

The results of our research showed that the youth accept a proactive attitude to life when their personal or family issues and events are in question, but that they do not see engagement in the social field and especially in a political one as a preferable type of behaviour. More precisely, they do not reject it a priori but believe that this type of engagement cannot lead to the desired outcomes. This, on the one hand, tells about the young people who cannot connect what happens in their lives with the general social and political developments. A number of them simply do not see themselves as "deeply rooted" in the system in which they live as though they did not share the fate of that system and as though they had no direct influence onto what occurs somewhere far away from them, against their will and desire. On the other hand, these findings do not speak only of the "guilt" of the youth for this attitude but also about a system that maybe does not ensure enough conditions for the youth to feel like they are part of the system and the community to which they belong.

A very small number of respondents - only 2 percent showed a completely passive attitude towards issues of personal and social activism. Slightly more than one-third - 35 percent was mainly passive, and almost one half of respondents - 48 percent, showed a moderate pro-active attitude. Finally, 15 percent claimed to be highly active in every type of engagement and acting.

Our results also pointed out that the strategy of each country is to allow the youth to achieve their goals in life and provide assistance to them in finding their place in the society. The level of youth activism, both in personal and social life, is one of the basic criteria determining whether the opportunities, being provided for young generations by the society, will be adequately exploited. Finally, it can be concluded that: "when youth are engaged, particularly when empowerment and development opportunities are provided, there are multiple benefits for society" (Maconachie, 2014; Powers \& Tiffany, 2006; Ho, Clarke \& Dougherty, 2015). 


\section{REFERENCES}

[1] Bendit, R. (2006). Youth sociology and comparative analysis in the European Union Member States. Papers: Revista de sociologia, (79), 49-76.

[2] Borojevic, T.,Petrovic, N.B., \& Vuk, D. (2014). Youth and Environmental Educationfor Sustainable Development. International Journal of Science and Research (IJSR), Volume 3 Issue 9, September 2014, 57-62.

[3] Cahill, C. (2010). 'Why do they hate us': reframing immigration through participatory action research. Area, 42(2), 152-161.

[4] Center for Free Elections and Democracy- CeSID \& Ministry of Youth and Sports. Report on the Active Participation of Young People in Societal Life. Belgrade: Ministry of Youth and Sports, 2007. (in Serbian)

[5] Ciszek, E.L. (2015). Bridging the gap: Mapping the relationship between activism and public relations. Public Relations Review. doi:10.1016/j.pubrev.2015.05.016.

[6] Conference Advisory Committee. Valjevo, November 2007. (in Serbian)

[7] Crawley, H. (2010). 'No one gives you a chance to say what you are: finding space for children's agency in the UK asylum system. Area, 42(2), 162-169.

[8] Elwood, S., \& Mitchell, K. (2012). Mapping children's politics: spatial stories, dialogic relations and political formation. Geografiska Annaler: Human Geography, 94(1), 1-15.

[9] Ho, E., Clarke, A., \& Dougherty, I. (2015). Youth-led social change: Topics, engagement types, organizational types, strategies, and impacts. Futures, 67(2015), 52-62.

[10] Hopkins, P. (2004). Young Muslim men in Scotland: inclusions and exclusions. Children's Geographies, 2(2), 257-272

[11] Hopkins, P. (2007). Global events, national politics, local lives: young Muslim men in Scotland Environment and Planning A, 39(5), 1119-1122.

[12] Hopkins, P., \& Todd, L. (2015). Creating an intentionally dialogic space: Student activism and the Newcastle Occupation 2010. Political Geography, 46(2015), 31-40.

[13] Horschelmann, K. (2008). Populating the landscape of critical geopolitics - young people's responses to the Iraq war (2003). Political Geography, 27(5), 587-609.

[14] Jović-Lazić, A. Activity of UNESCO and membership of the state union of Serbia and Montenegro. Yearbook 2000-2003, Belgrade: Association for the international, 2004. (in Serbian)

[15] Kallio, K. P., \& Hakli, J. (2011). Tracing children's politics. Political Geography, 30(2), 99-109.

[16] Maconachie, R. (2014). Dispossession, exploitation or employment? Youth livelihoods and extractive industry investment in Sierra Leone. Futures, 62(Part A(0)), 75-82. http://dx.doi.org/10.1016/j.futures.2013.08.003.

[17] Ministry of Youth and Sports (2008). National strategy for youth. Retrieved from http://www.ombudsman.pravadeteta.compercent2Fattachmentspercent2F286_NACIONALNApercent 2520STRATEGIJApercent2520zapercent2520mlade.doc\&ei $=\mathrm{t}-$ uGVZv0M8GMsAGy2b6wCQ\&usg=AFQjCNHv9oqmeAK0ie11-HmCf8QylsGvwg\&sig2=TrxeOBWh11 WsDMT47NPJog\&bvm=bv.96339352,d.bGg. (in Serbian)

[18] Ministry of Youth and Sports (2015). National Youth Strategy for the period 2015 - 2025. Retrieved from http://www.mos.gov.rs/wp-content/uploads/download-manager-files/NSMpercent2020152025percent20ENGLISHpercent20.pdf. (in Serbian)

[19] Mitchell, K., \& Elwood, S. (2013). Intergenerational mapping and the cultural politics of memory. Space and Polity, 17(1), 33-52.

[20] Pain, R., Panelli, R., Kindon, S., \& Little, J. (2010). Moments in everyday/distant geopolitics: young people's fears and hopes. Geoforum, 41(6), 972-982.

[21] Powers, J., \& Tiffany, J. (2006). Engaging youth in participatory research and evaluation. Journal of Public Health Management and Practice, 12(Suppl. 6), S79-S87.

[22] Smith, M.F. (1997). Activism. In R. L. Heath (Ed.), Encyclopedia of public relations (pp. 5-10). Thousand Oaks, CA: Sage.

[23] Staeheli, L., Attoh, K., \& Mitchell, D. (2013). Contested engagements: youth and the politics of citizenship. Space and Polity, 17(1), 88-105.

[24] Taylor, M., \& Das, S. (2010). Public relations in advocacy: Stem cell research organizations' use of the Internet in resource mobilization. Public Relations Journal, 4(4) http://www.prsa.org/Intelligence/PRJournal/Documents/2011FallTaylorDas.pdf.

[25] United Nations - UN (2015). Definition of Youth. Retrieved from http://www.un.org/esa/socdev/documents/youth/fact-sheets/youth-definition.pdf.

[26] United Nations Volunteers - UNV (2015). How to volunteer. Retrieved from http://www.unv.org/how-tovolunteer.html. 
Zoller, H. (2009). Narratives of corporate change: Public participation through environmental health activism, stakeholder dialogue, and regulation. In L. M. Harter, M. J. Dutta, \& C. E. Cole (Eds.), Communication for social impact: Engaging communication theory, research, and pedagogy (pp91-114). Cresskill, NJ: Hampton Press.

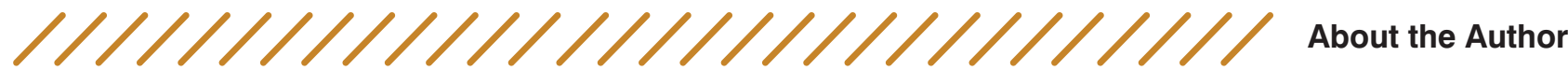

Tatjana Borojević University of Maribor, Faculty of Organizational Sciences, Slovenia

Tatjana Borojević is a PhD student at the Faculty of Organizational Sciences, University of Maribor, the Republic of Slovenia. She has over 13 years of work experience in the fields of social policy, youth policy and reform of public administration, based on civil society strengthening, local government capacity building and community development. The key areas of her interest are decentralisation processes in the Republic of Serbia in the fields of social and youth policy with specalisation in the social aspect of transition.

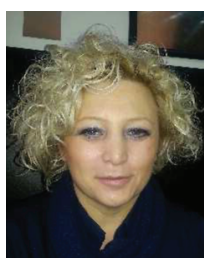

\section{Drago Vuk \\ University of Maribor, Faculty of Organizational Sciences, Slovenia}

Dr Drago Vuk is a full professor at the Faculty of Organizational Sciences, University of Maribor, the Republic of Slovenia, where he acquired his Ph.D. (1986) degree in Environmental management. The areas of his research include: Environmental management, Environmental science, Sustainable development and Environmental education.

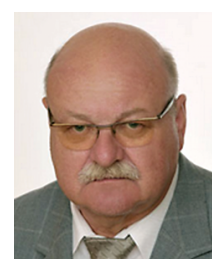

Nataša Petrović
University of Belgrade, Faculty of Organizational Sciences,Serbia

Dr Nataša B. Petrović is a full professor at the Faculty of Organizational Sciences, University of Belgrade, the Republic of Serbia, where she acquired her M.Sc. (1999) and Ph.D. (2002) degrees in Environmental management. The areas of her research include:

Environmental management, Environmental science, Sustainable development, Green marketing, Environmental education and Education for sustainable development, Environmental risk management, Energy efficiency, Management skills for environmental managers, Public participation in environmental protection.

Dragoslav Slović University of Belgrade, Faculty of Organizational Sciences,Serbia

Dragoslav R. Slović is an associate professor at the Faculty of Organizational Sciences, University of Belgrade, the Republic of Serbia. He graduated and received his PhD degree in industrial engineering and management from the University of Belgrade -

Faculty of Organizational Sciences. The key areas of his scientific interest are performance and compensation management and production efficiency increasing by the application of continuous processes improvement, Lean and Kaizen approach and

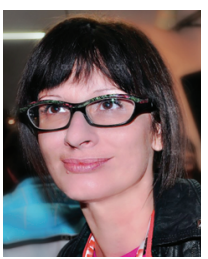
fundamentals of industrial engineering. 